\title{
NOTES ON THE LICHEN GENUS OCHROLECHIA IN BOLIVIA
}

\author{
MARTIN KUKwa, PAMEla Rodriguez Flakus \& AdAM FlaKuS
}

\begin{abstract}
The paper presents new records for four taxa of Ochrolechia A. Massal. from Bolivia, of which three, O. austroamericana (Räsänen) Räsänen, O. subpallescens f. Verseghy uruguayensis Verseghy and O. upsaliensis (L.) A. Massal., are new for the country. Ochrolechia subpallescens f. uruguayensis is shown to differ chemically from O. subpallescens s.str., but its taxonomic rank needs to be clarified with molecular studies. Ochrolechia africana Vain. is also reported for the first time for Tanzania and Uruguay, and O. austroamericana for Ecuador.
\end{abstract}

Key words: biogeography, lichenized fungi, Neotropics, South America

Martin Kukwa, Department of Plant Taxonomy and Nature Conservation, University of Gdańsk, Wita Stwosza 59, 80-308 Gdańsk, Poland; e-mail: dokmak@ug.edu.pl

Pamela Rodriguez Flakus, Department of Botany and Molecular Evolution, Senckenberg Forschungsinstitut und Naturmuseum, Senckenberganlage 25, D-60325, Frankfurt am Main, Germany, and Herbario Nacional de Bolivia, Instituto de Ecología, Universidad Mayor de San Andrés, Calle 27, Cota Cota, Casilla 10077, La Paz, Bolivia

Adam Flakus, Laboratory of Lichenology, W. Szafer Institute of Botany, Polish Academy of Sciences, Lubicz 46, 31-512 Kraków, Poland

\section{INTRODUCTION}

Despite intensive studies of lichens in tropical and temperate regions of South America, numerous genera are still poorly investigated. One of those is Ochrolechia A. Massal. Some records, including newly described taxa, were published by Verseghy (1962) in her world monograph, but these are not reliable due to numerous misidentifications of secondary metabolites and overestimation of morphological characters (e.g., Brodo 1991). More recent reports by Messuti and Lumbsch (2000) and Messuti and Vobis (2002) refer to species from southern South America. Occasionally they are given as additional material in taxonomic treatments of species from other continents (e.g., Brodo 1991; Kukwa 2011). The occurrence of Ochrolechia in many countries on the continent is still very poorly known, and Bolivia is no exception. Only two species were known from Bolivia: $O$. africana Vain. and $O$. parella (L.) A. Massal. The first was recently reported as host of the lichenicolous fungus Cornutispora lichenicola D. Hawksw. \& B. Sutton from a single locality (Flakus \& Kukwa 2012), and the second was recorded as Lecanora parella (L.) Ach. by Nylander (1861) from tree bark. Ochrolechia parella, as presently circumscribed, represents a saxicolous lichen confirmed only from Eurasia and North Africa (Kukwa 2011), so we consider the Bolivian record to be a misidentification. The specimen published by Nylander (1861) may represent the superficially similar $O$. africana but this cannot be confirmed as no reference material was found in H-Nyl.

In this paper we report four taxa of Ochrolechia, three of which are new for Bolivia.

\section{MATERIAL AND METHODS}

The study is based on samples we collected (deposited in KRAM, LPB and UGDA) and other collections deposited in B, BP, BM, H, LINN, PRA, W and the private herbarium of Professor Mark Seaward. Specimens were examined using standard microscopic techniques. Secondary metabolites were determined by thin-layer chromatography (TLC) in solvents A, B (or B') and C (methods according to Culberson and Kristinsson 1970, and Orange et al. 2001). The reactions 
with $\mathrm{C}$ (commercial bleach) of the thallus and apothecial structures were also checked.

The following abbreviations are used: $A F-\mathrm{A}$. Flakus, $J Q-$ J. Quisbert, $M K-$ M. Kukwa, $O P-\mathrm{O}$. Plata, $P R$ - P. Rodriguez Flakus, PN - Parque Nacional, PNANMI - Parque Nacional Área Natural de Manejo Integrado, ANMIN - Área Natural de Manejo Integrado Nacional.

\section{THE SPECIES}

\section{Ochrolechia africana Vain.}

Annal. Univ. Fenn. Aboensis Ser. A 2(3): 3. 1926. TYPE: SOUTH AFRICA, Durban. Trunk of tree. 1921, van der Bijl 136 (TUR-V 34315, HOLOTYPE).

The species can be recognized by its small, often pruinose apothecia with smooth margins, rugose to verruculose thallus, and apothecial margin with C + red medulla and C- cortex (Brodo 1991). Its chemistry is very diverse; Brodo (1991) distinguished eight chemotypes, all of which contain gyrophoric acid (always together with lecanoric acid), but they vary by the presence or absence of lichexanthone, 5-O-methylhiascic acid and 4,5-di$O$-methylhiascic acid. We found three chemotypes in our Bolivian material: chemotype 3 with lichexanthone and 4,5-di- $O$-methylhiascic acid, chemotype 4 containing lichexanthone, and chemotype 6 with 5-O-methylhiascic acid.

The saxicolous specimens cited below could be considered to be $O$. peruensis Verseghy, but according to Lumbsch et al. (2003) that species lacks lichexanthone. However, O. peruensis may represent a saxicolous morph of $O$. africana lacking lichexanthone, as morphologically and chemically (the holotype contains gyrophoric, 4,5-di- $O$-methylhiascic and 5-O-methylhiascic acids) it is very similar to $O$. africana, but this needs to be checked by molecular analyses.

Ochrolechia africana was reported from tropical to subtropical areas of Australia, Asia (Bhutan, India, Taiwan), Central and North America (e.g., Costa Rica, Cuba, Mexico, USA), South Africa and South America (e.g., Argentina, Bolivia, Brazil, Paraguay) (Brodo 1991; Allen et al. 2001; Aptroot \& Feijen 2002; Aptroot \& Sparrius 2003; Singh \& Sinha 2010; Flakus \& Kukwa 2012). In
Bolivia it was known from a single locality up to now (Flakus \& Kukwa 2012). In this paper it is reported for the first time from Tanzania and Uruguay.

SELECTED SPECIMENS EXAMINED. BOLIVIA. DEPT. LA PAZ. Prov. Franz Tamayo, between Apolo and Mapiri villages, $14^{\circ} 50^{\prime} 51^{\prime \prime} \mathrm{S}, 68^{\circ} 21^{\prime} 38^{\prime \prime} \mathrm{W}, 1490 \mathrm{~m}$, artificial savannah with scattered trees, on twig, 23 Nov. 2011, MK 10268 (LPB, UGDA; chemotype 6); Prov. Nor Yungas, Coroico village, $16^{\circ} 11^{\prime} 10^{\prime \prime} \mathrm{S}, 67^{\circ} 43^{\prime} 16^{\prime \prime} \mathrm{W}$, $1550 \mathrm{~m}$, Yungas montane forest, on bark, 6 June 2010, $A F$ 16423.1 \& PR (KRAM, LPB; chemotype 3); near Pongo village, $16^{\circ} 19^{\prime} 28^{\prime \prime} \mathrm{S}, 67^{\circ} 57^{\prime} 21^{\prime \prime} \mathrm{W}, 3822 \mathrm{~m}$, Páramo Yungueńo, on twigs, 26 Nov. 2011, MK $10456 a$ (LPB, UGDA; chemotype 6); DEPT. SANTA CruZ. Prov. Cordillera, PNANMI Kaa-Iya del Gran Chaco, $18^{\circ} 28^{\prime} 05^{\prime \prime} \mathrm{S}, 62^{\circ} 05^{\prime} 43^{\prime \prime} \mathrm{W}, 307 \mathrm{~m}$, Chaqueńo forest, Charrata village, on bark, 2 Dec. 2010, AF 20185 , 20194 \& JQ (KRAM, LPB; chemotype 4); between Tucavaca and Roboré, $18^{\circ} 37^{\prime} 56^{\prime \prime} \mathrm{S}, 59^{\circ} 36^{\prime} 50^{\prime \prime} \mathrm{W}$, $370 \mathrm{~m}$, transition Chiquitano-Chaqueńo forest, on twig, 04 Dec. 2011, MK 10552 (LPB; chemotype 6); Prov. Florida, PNANMI Ámboro, La Yunga village, $18^{\circ} 05^{\prime} 59^{\prime \prime} \mathrm{S}, 63^{\circ} 56^{\prime} 55^{\prime \prime} \mathrm{W}, 1648 \mathrm{~m}$, transition YungasChiquitano forests, on rock, 8 June 2011, $A F$ 22576, $M K 9957$ \& OP (KRAM, LPB, UGDA; chemotype 4). TANZANIA. TANGA Prov. Usambara Mts, Amani, road towards $\mathrm{SW}, 800-900 \mathrm{~m}, 5^{\circ} 08^{\prime} \mathrm{S}, 38^{\circ} 37^{\prime} \mathrm{E}$, on bark, 11 Jan. 1971, O. Vitikainen 9431 (H, chemistry not tested by TLC). URUGUAY. DEPT. CANELONES. PN 'F. D. Roosevelt', by artificial lake, on Eucalyptus sp., 4 Jan. 1986, H. S. Osorio 8594 (herb. Seaward 105288; chemotype 6). A total of 10 Bolivian specimens seen.

SPECIMENS OF OCHROLECHIA PERUENSIS EXAMINED. PERU. Lima, 1868-1871, Wawra (W, holotype).

\section{Ochrolechia austroamericana (Räsänen)}

Räsänen

Anal. Soc. Cient. Argent. 131: 100. 1941. - Ochrolechia pallescens var. austroamericana Räsänen, Anal. Soc. Cient. Argent. 128: 138. 1939. - TYPE: [Argentina, Patagonia, Prov. Neuquén] Parque de N. H. [Nahuel Huapí], Valle Limay, $5 \mathrm{~km}$ austr. Lipela, en rocas. ca. 750 m. 12.X.1936. D. [A. Donat] (H!, HOLOTYPE).

According to Messuti and Lumbsch (2000) $O$. austroamericana is distinguished by its verrucose to areolate, brownish grey to brown thallus, 
pruinose discs, mostly 8 -spored asci, rather small ascospores, $17-25 \times 10-20 \mu \mathrm{m}$, and gyrophoric acid as the main secondary substance.

In the studied material we observed additional features not reported before. In some Bolivian specimens the ascospores were larger than reported before, reaching up to $31(-35) \mu \mathrm{m}$ in length. The algal layer in the apothecia is always present in the amphithecium, but below the hypothecium it is often absent. We also observed considerable variation in hypothecium color; in some specimens it was very pale and in others distinctly orangeyellow to orange. The species may rarely form soralia, and up to now one such specimen has been reported (Messuti \& Lumbsch 2000). In Bolivia we discovered sorediate morphs of $O$. austroamericana on three localities.

The species is known only from South America, where it has been reported from Argentina, Chile and Uruguay (Messuti \& Lumbsch 2000; Kukwa 2011). In this paper it is reported from numerous localities in Bolivia and one in Ecuador. These records extend the known distribution of the species much northward.

SELECTED SPECIMENS EXAMINED (all saxicolous). BOLIVIA. DePt. LA PAZ. Prov. Bautista Saavedra, ANMIN Apolobamba, near Villa Amarca village, $15^{\circ} 16^{\prime} 47^{\prime \prime} \mathrm{S}, 69^{\circ} 01^{\prime} 47^{\prime \prime} \mathrm{W}, 4643 \mathrm{~m}$, Puna Húmeda, 3 July 2010, AF 17367 \& PR (KRAM, LPB); Prov. Camacho, near Villa Cala village, $15^{\circ} 25^{\prime} 53^{\prime \prime} \mathrm{S}$, $69^{\circ} 05^{\prime} 07^{\prime \prime} \mathrm{W}, 4250 \mathrm{~m}$, high Andean vegetation, on rock, 19 May 2011, AF 21197 (KRAM, LPB); Pacoamba near Wila Kala, $15^{\circ} 24^{\prime} 40^{\prime \prime} \mathrm{S}, 69^{\circ} 04^{\prime} 24^{\prime \prime} \mathrm{W}, 4283 \mathrm{~m}$, Puna Húmeda, 6 July 2010, $A F 17698$ \& PR (KRAM, LPB, UGDA-L); Prov. Franz Tamayo, Pelechucomita hill by Puyo Puyo village, $15^{\circ} 01^{\prime} 18.94^{\prime \prime} \mathrm{S}, 69^{\circ} 08^{\prime} 48.07^{\prime \prime} \mathrm{W}$, $5050 \mathrm{~m}$, high Andean vegetation, 25 Apr. 2008, PR 554 (LPB); ANMIN Apolobamba, Socondori Chico near Ulla Ulla village, $15^{\circ} 00^{\prime} 38^{\prime \prime} \mathrm{S}, 6^{\circ} 13^{\prime} 48^{\prime \prime} \mathrm{W}, 4479 \mathrm{~m}$, high Andean open vegetation, 4 July 2010, $A F$ 17440, 17442 \& PR (KRAM, LPB); Prov. Manco Kapac, near Copacabana village, Mt. Horca del Inca, $16^{\circ} 10^{\prime} 15^{\prime \prime} \mathrm{S}$, $69^{\circ} 05^{\prime} 05^{\prime \prime} \mathrm{W}, 3974 \mathrm{~m}$, high Andean Puna, on rock, 18 June 2006, $A F 8669$ (KRAM, LPB); Prov. Murillo, PN Tuni Condoriri, Tuni village, Mt. Condor Pustańa, $16^{\circ} 13^{\prime} 27.70^{\prime \prime} \mathrm{S}, 68^{\circ} 16^{\prime} 03.40^{\prime \prime} \mathrm{W}, 4862 \mathrm{~m}$, high Andean vegetation, 17 March 2009, PR 974 (LPB); Prov. Nor Yungas, near Pongo village, $16^{\circ} 19^{\prime} 28^{\prime \prime} \mathrm{S}, 67^{\circ} 57^{\prime} 21^{\prime \prime} \mathrm{W}$, 3820 m, Páramo Yungueńo, 25 May 2011 MK 9407
(LPB, UGDA); Prov. Omasuyos, El Dragon hill near Chahualla, $15^{\circ} 51^{\prime} 17^{\prime \prime} \mathrm{S}, 69^{\circ} 00^{\prime} 40^{\prime \prime} \mathrm{W}, 3850 \mathrm{~m}$, Puna Húmeda, 06 July 2010, $A F 17839$ \& $P R$ (KRAM, LPB); DEPT. ORURO. Prov. Sajama, PN Sajama, near Sajama village, $18^{\circ} 07^{\prime} 49^{\prime \prime} \mathrm{S}, 68^{\circ} 56^{\prime} 54^{\prime \prime} \mathrm{W}, 4437 \mathrm{~m}$, Puna Sureña, 18 June 2010, $A F 16455 \& P R$ (KRAM, LPB). ECUADOR. PICHINCHA PROV. Guamaní (Páramo de la Virgen), moist Páramo $\mathrm{N}$ of road between Pifo and Papallacta, ca $25 \mathrm{~km} \mathrm{WSW}$ of Quito, $00^{\circ} 18^{\prime} \mathrm{S}, 78^{\circ} 12^{\prime} \mathrm{W}$, 4200 m, 19 June 1999, Z. Palice 2280 (PRA). A total of 29 Bolivian specimens seen.

SOREDIATE SPECIMENS EXAMINED (all saxicolous). BOLIVIA. DePT. LA PAZ. Prov. Murillo, PN Tuni Condoriri, Tuni village, Mt. Paco Thojo, $16^{\circ} 12^{\prime} 31.30^{\prime \prime} \mathrm{S}$, $68^{\circ} 16^{\prime} 12.30^{\prime \prime} \mathrm{W}, 5014 \mathrm{~m}$, high Andean vegetation, 18 March 2009, PR 1030, 1038, 1056 (LPB); below Potosí, on road between La Paz and Valle del Zongo, $16^{\circ} 17^{\prime} 43^{\prime \prime} \mathrm{S}, 68^{\circ} 07^{\prime} 42^{\prime \prime} \mathrm{W}, 4720 \mathrm{~m}$, high Andean vegetation, 28 May 2011, MK 9493 (LPB, UGDA); DEPT. ORURO. Prov. Sajama, PN Sajama, near Sajama village, $18^{\circ} 07^{\prime} 49^{\prime \prime} \mathrm{S}, 68^{\circ} 56^{\prime} 54^{\prime \prime} \mathrm{W}, 4437 \mathrm{~m}$, Puna Sureña, tholares vegetation, 18 June 2010, $A F 16502 \& P R$ (KRAM, LPB).

\section{Ochrolechia subpallescens Verseghy f. uruguayensis Verseghy}

Beih. Nova Hedwigia 1: 119. 1962. - TYPE: URUGUAY: Flores-Ruta $3 \mathrm{~km}$. 241. Sobre Melia azedarach a 1/4 km. al oeste de la escuela Marincho, H.S. Osorio. Herbario Hector Osorio No 3585 (B 32260!, BP 20054!, herb. Seaward 108721!, ISOTYPES).

Verseghy (1962) characterized O. subpallescens f. uruguayensis as differing from the morphologically and anatomically similar $O$. $s u b$ pallescens s.str. by its chemistry and distribution. Verseghy's chemical data have been questioned (Brodo 1991), however, so we re-examined the type material and some additional specimens of both names. The samples of the two taxa are almost identical morphologically, with thick, rugose or verruculose thalli, a prominent, smooth apothecial margin, and epruinose apothecial discs. They differ in secondary chemistry: $O$. subpallescens s.str. almost always contains olivetoric and 3-O-demethylmicrophyllinic acids (see also Brodo 1991), whereas all examined specimens of $O$. subpallescens $\mathrm{f}$. uruguayensis lack these substances. They also differ in the $\mathrm{C}$ reaction of apothecial 
structures: in both taxa the margin cortex and disc are $\mathrm{C}+$ red, but the margin medulla reacts red with $\mathrm{C}$ only in O. subpallescens $\mathrm{f}$. uruguayensis. Since chemical features, especially the placement of secondary metabolites in the margin medulla and cortex, have been found to be taxonomically important in at least some Ochrolechia groups (Brodo 1991), we keep the two taxa separate, but a macromolecular analysis is needed to determine whether O. subpallescens f. uruguayensis deserves species rank.

The reactions of the apothecial margin of O. subpallescens f. uruguayensis are identical to those of $O$. mexicana Vain. The two taxa are also similar in general habit, as both have thick thalli and epruinose apothecial discs. The main difference is in their chemistry: O. mexicana contains lichexanthone and 4,5-di- $O$-methylhiascic acid. A rare chemical race of this species may lack 4,5-di-O-methylhiascic acid, but then the margin medulla is C negative (Brodo 1991).

Ochrolechia subpallescens f. uruguayensis has been reported so far only from Uruguay (e.g., Verseghy 1962; Osorio 2007). The Bolivian locality is the northernmost record of the species.

SPeCimens EXAmined. BOLIVIA. DePt. CochaBAMBA. Prov. Carrasco, PN Carrasco, near Sehuencas village, $17^{\circ} 30^{\prime} 12^{\prime \prime} \mathrm{S}, 65^{\circ} 16^{\prime} 30^{\prime \prime} \mathrm{W}, 2220 \mathrm{~m}$, along the road in Yungas cloud forest, on tree, 21 July 2008, $M K$ 6313, 6369 (LPB, UGDA). URUGUAY. DEPT. ROCHA. Sierra de San Miguel, Cerro de la Guardia Perdida, $33^{\circ} 42^{\prime} \mathrm{S}, 53^{\circ} 34^{\prime} \mathrm{W}$, meadow, on rock, 11 June 1989 , H. S. Osorio 9168 (herb. Seaward).

\section{Ochrolechia upsaliensis (L.) A. Massal.}

Ric. Auton. Lich. Crost.: 31. 1852. - Lichen upsaliensis L., Sp. Pl. 2: 1142. 1753. - TYPE: unlocalized specimen, but according to the protologue 'Upsalia' (LINN-1273.44!, upper right-hand specimen, LECTOTYPE).

This terricolous lichen is characterized by its often yellow apothecia with thick, scabrose to coarsely pruinose discs, not or partly expanded and never hyaline basal margin cortex, and the production of variolaric acid, which is often accompanied by the murolic acid complex and two unidentified substances named "microstictoides unknowns" (Kukwa 2011). All these substances were detected in our Bolivian material. One specimen also contained two unidentified fatty acids in Rf classes A1 and A1-2 (not found in other solvents), apparently similar to those found by Kukwa (2011) in European samples.

Ochrolechia upsaliensis is known from numerous localities in Europe and North America, and a few records from Asia, Africa (Canary Islands) and South America (Argentina) (e.g., Hafellner 1995; Calvello \& Liberatore 2002; Kukwa 2011). In South America it was also reported from Colombia (Verseghy 1962), but this record is considered erroneous (Sipman et al. 2008). In Bolivia it was found at only a single locality so far. This is also the first record from South America confirmed by TLC.

SpeCimens eXamined. BOLIVIA. DePt. La PaZ. Prov. Franz Tamayo, ANMIN Apolobamba, Puntani hill, by guards' office of ANMIN Apolobamba, $15^{\circ} 01^{\prime} 50.26^{\prime \prime} \mathrm{S}, 69^{\circ} 11^{\prime} 08.89^{\prime \prime} \mathrm{W}, 4770 \mathrm{~m}$, high Andean vegetation, 23 Apr. 2008, PR 578 (LPB), Pelechucomita hill near Puyo Puyo village, $15^{\circ} 01^{\prime} 18.94^{\prime \prime} \mathrm{S}$, $69^{\circ} 08^{\prime} 48.07^{\prime \prime} \mathrm{W}, 5050 \mathrm{~m}$, high Andean vegetation, on plant remains, 25 Apr. 2008, PR 618 (LPB, UGDA).

ACKNOWLEDGEMENTS. We are greatly indebted to Rosa I. Meneses Q., Director of Herbario Nacional de Bolivia, Instituto de Ecología, Universidad Mayor de San Andrés, La Paz, for her generous cooperation. We also thank the curators of all the herbaria for their hospitality during the visits of the first author or for the loan of specimens, Javier Quisbert and Oscar Plata (La Paz) for help during the field work, and Harrie J. M. Sipman (Berlin) for helpful remarks on the manuscript. This research received support from the National Center for Research and Development (NCBiR) in Poland under the LIDER Program for 2010-2013 (no. 92/L-1/09).

\section{REFERENCES}

Allen D., Lumbsch H. T., Madden S. \& Sipman H. J. M. 2001. New Australian and Australian state lichen and lichenicolous lichen reports. J. Hattori Bot. Lab. 90: 269-291.

Aptroot A. \& FeiJen F. J. 2002. Annotated checklist of the lichens and lichenicolous fungi of Bhutan. Fung. Diversity 11: $21-48$. 
Aptroot A. \& SPARriUs L. B. 2003. New microlichens from Taiwan. Fung. Diversity 14: 1-50.

BRodo I. M. 1991. Studies in the lichen genus Ochrolechia. 2. Corticolous species of North America. Canad. J. Bot. 69: 733-772.

Calvelo S. \& Liberatore S. 2002. Catálogo de los líquenes de la Argentina. Kurtziana 29(2): 7-170.

Culberson C. F. \& Kristinsson H. 1970. A standardized method for the identification of lichen products. J. Chromatogr. 46: 85-93.

FlaKus A. \& KUKWA M. 2012. New records of lichenicolous fungi from Bolivia. Opuscula Philolichenum 11: 36-48.

HAFELLNER J. 1995. A new checklist of lichens and lichenicolous fungi of insular Laurimacaronesia including a lichenological bibliography for the area. Fritschiana 5: $1-132$.

KuKWA M. 2011. The lichen genus Ochrolechia in Europe. Fundacja Rozwoju Uniwersytetu Gdańskiego, Gdańsk.

Lumbsch H. T., Messuti M. I. \& NAsh T. H. III 2003. Ochrolechia splendens (Pertusariaceae), a new species from south-western North America. Lichenologist 35: 387-391.

Messuti M. I. \& Lumbsch H. T. 2000. A revision of the genus Ochrolechia in southern South America. Biblioth. Lichenol. 75: 33-46.
Messuti M. I. \& VoBIS G. 2002. Fungi (Lichenes), Ascomycetes. Pertusariales: Coccotremataceae, Megasporaceae y Pertusariaceae. Fl. Criptog. Tierra del Fuego 13: 5-106.

NYLANDER W. 1861. Additamentum ad lichenographiam Andium Boliviensium. Ann. Sci. Nat., Bot. 15: 365-382.

Orange A., James P. W. \& White F. J. 2001. Microchemical methods for the identification of lichens. British Lichen Society, London.

OSORIO H. S. 2007. Contribution to the lichen flora of Uruguay XLII. Additions and corrections. Comunicaciones Botánicas Museos Nacionales de Historia Natural y Antropologia 133(6): 1-7.

SINGH K. P. \& SinHA G. P. 2010. Indian lichens: an annotated checklist. Botanical Survey of India, Ministry of Environment and Forests, Salt Lake City, Kolkata.

Sipman H. J. M., HeKking W. \& AguirRe-C. J. 2008. Checklist of Lichenized and Lichenicolous Fungi from Colombia. Biblioteca José Jerónimo Triana 20. Instituto de Ciencias Naturales, Facultad de Ciencias, Universidad Nacional de Colombia, Bogotá.

VERSEGHY K. 1962. Die Gattung Ochrolechia. Nova Hedwigia Beih. 1: 1-146.

Received 20 August 2013 